\title{
Effects of black cohosh on estrogen biosynthesis in hippocampus of non- human primates ex vivo in vitro and in human neuroblastoma cells in vitro
}

Petra Stute ${ }^{1,5^{*}}$, Gunnar Habermann ${ }^{2}$, Ludwig Kiesel ${ }^{3}$, Hans-Heinrich Henneicke-von Zepelin ${ }^{4}$ and Susana Garcia de Arriba ${ }^{4}$

\begin{abstract}
Background: Estrogens have neuroprotective properties. The aim of the study was to assess the impact of an isopropanolic extract of Cimicifuga racemosa (iCR), 17ß-estradiol (E2), testosterone (T) and Tibolone's 3a-OH metabolite (Org4094) on local estrogen formation in hippocampus tissue from non-human primates ex vivo in vitro and human neuroblastoma cells (SH-SY5Y) in vitro.

Methods: SH-SY5Y cells were incubated in RPMI 1640 medium containing $5 \%$ steroid-depleted fetal calf serum for 3 days, and subsequently incubated in absence or presence of iCR at $10 \mu \mathrm{g} / \mathrm{ml}(n=5)$ and $1 \mu \mathrm{g} / \mathrm{ml}(n=5)$, E2 at 10 ${ }^{-8} \mathrm{M}(n=5)$, and $10^{-6} \mathrm{M}(n=5)$, or $\mathrm{T}$ at $10^{-8} \mathrm{M}(n=5)$, and $10^{-6} \mathrm{M}(n=5)$, respectively, at $37^{\circ} \mathrm{C}$ for either $24 \mathrm{~h}$ or directly in cell extracts. Hippocampus tissue from healthy female cynomolgus macaques $(n=14)$ was homogenized and treated with iCR, E2 and Org4049 accordingly. STS activity was evaluated by incubating homogenized brain cells and tissue with [3H]-estrone sulfate and separating the products estrone (E1) and E2 by thin layer chromatography. STS activity was expressed as total estrogen formation (E1 + E2) fmol/mg of protein/min. Statistical comparisons were made using unpaired T-Test for comparing two sets of data and ANOVA to compare many groups at once. A $p$ value $<0.05$ was considered to be significant different.

Results: Basal total estrogen formation was significantly higher in proliferative SH-SY5Y cells $(1350.06 \pm 109$ E1 + E2 $\mathrm{fmol} / \mathrm{mg}$ of protein/min) compared to hippocampus tissue (37.83 $\pm 3.9 \mathrm{E} 1+\mathrm{E} 2 \mathrm{fmol} / \mathrm{mg}$ of protein $/ \mathrm{min} ; p<0.01$ ). ICR exerted a bidirectional action with an immediate strong inhibitory effect being followed by a stimulation of STS activity ( $85 \%$ increase). E2 had a bidirectional dose-dependent long-term effect on STS activity ( $-23 \%$ reduction and $18 \%$ increase). $T$ and Org4094 had an immediate strong inhibitory effect on STS activity that further maintained with $24 \mathrm{~h} \mathrm{~T}$ treatment (30\% decrease).
\end{abstract}

Conclusions: Local estrogen formation within brain cells and tissue may be modulated by black cohosh, 17ß-estradiol, testosterone, and Tibolone's 3a-OH metabolite, respectively. The clinical implication of this finding has to be elucidated. Keywords: Steroid sulfatase, Brain, Hippocampus, Non-human primates, Black cohosh, Estradiol, Testosterone, Tibolone

\footnotetext{
* Correspondence: petra.stute@insel.ch

${ }^{1}$ Department of Obstetrics and Gynecology, Inselspital, University Hospital

and University of Bern, Effingerstrasse 102, 3010 Bern, Switzerland

${ }^{5}$ Department of Obstetrics and Gynecology, Section Gynecologic

Endocrinology and Reproductive Medicine, Inselspital Bern, Effingerstrasse

102, 3010 Bern, Switzerland

Full list of author information is available at the end of the article
}

\section{Springer}

(C) 2016 Stute et al. Open Access This article is distributed under the terms of the Creative Commons Attribution 4.0 International License (http://creativecommons.org/licenses/by/4.0/), which permits unrestricted use, distribution, and reproduction in any medium, provided you give appropriate credit to the original author(s) and the source, provide a link to the Creative Commons license, and indicate if changes were made. 


\section{Background}

The sex steroid 17ß-Estradiol (E2) displays neuroprotective and -reparative properties by, e.g. promoting neuronal survival, neuritogenesis and synaptic function, reducing local inflammation of astrocytes and microglia, and facilitating remyelination, respectively [1]. Specifically, estrogens seem to display these characteristics when initiated during the critical window of opportunity close to menopause [2]. Brain, as other tissues, possesses the enzymes necessary for local formation of active hormones, neurosteroids, from inactive precursor hormones. They predominantly use (non-genomic) signaling pathways common for neuromodulators such as modulating the activity of several neurotransmitter receptors. Neurosteroids occur as free unconjugated steroids, sulfate esters or fatty acids esters [3]. Conjugated and unconjugated neurosteroids differ in their metabolic, behavioral and psychological effects, e.g. in cognition [4]. Thus, the enzyme steroid sulfatase (STS) plays a major role as it regulates the equilibrium between sulfated and free neuroactive steroids in the brain [5]. An imbalance in the ratio of unconjugated steroid/steroid sulfate has been shown to have an impact on memory and longterm potentiation in the hippocampus [6, 7]. Interestingly, increased dehydroepiandrosterone sulfate (DHEAS) rather than DHEA level has been found to enhance memory possibly by positively influencing brain cholinergic function $[8,9]$ and decreasing $\Upsilon$-amino butyrate $\left(\mathrm{GABA}_{\mathrm{A}}\right)$ ergic receptor activity [10]. In contrast, unconjugated neurosteroids are thought to act on $\mathrm{GABA}_{\mathrm{A}}$ receptors as positive modulators [11].

The risk of cognitive decline increases with age. Thus, menopausal hormone therapy (MHT) containing estrogens, androgens or the synthetic steroid tibolone, respectively, would be expected to have a positive impact on cognition. However, so far MHT has yielded conflicting results and is not recommended for dementia prevention $[12,13]$. Herbs such as black cohosh are also frequently used for vasomotor symptom relief in menopausal women. There is some evidence that black cohosh has some neuroprotective effects [14].

Under the hypothesis that an increase of local estrogen formation has a positive impact on memory, the aim of our study was to investigate the effect of black cohosh on STS enzyme activity in hippocampus tissue ex vitro in vivo and neurons in vitro, respectively, in comparison to E2, T, and an estrogenic metabolite of tibolone.

\section{Methods}

\section{Chemical, reagents, and steroids}

The iCR (B. Nr. 010720) was provided by Schaper \& Bruemmer GmbH \& Co.KG. Salzgitter, Germany. The concentration of the extract was $100 \mathrm{mg} / \mathrm{ml}$ in relation to the dry residue. Alcohol concentration was $40 \%$ (v/ v). Tibolone's 3 $\alpha-\mathrm{OH}$ metabolite (Org4094) was provided by NV Organon (Oss, the Netherlands). The radioactive labeled steroid $[3 \mathrm{H}]-\mathrm{E} 1 \mathrm{~S}$ (specific activity $57.3 \mathrm{Ci} / \mathrm{mmol}$ ) was purchased from Perkin Elmer Life and Analytical Sciences (549 Albany Street, Boston, MA, USA). Unlabeled E2 and E1 were obtained from Sigma. Unless stated otherwise, all chemicals were from SigmaAldrich $^{\oplus}$ (Deisenhofen, Germany).

\section{Neuroblastoma cells and hippocampus tissue}

The human neuroblastoma cell line SH-SY5Y was purchased from the Leibniz Institute DSMZ-German Collection of Microorganisms and Cell Cultures (DSMZ; no ACC 209). Hippocampus tissues were used from lactating female control cynomolgus monkeys (Macaca fascicularis) that were euthanized in the course of other experiments. In brief, 14 adult female cynomolgus macaques ranging from 4 to 8 years of age were obtained from Vietnam $(n=5)$ and Mauritius $(n=9)$, respectively. Each animal was clinically evaluated and determined to be in good health. In order to monitor the welfare of an individual or a group of animals, additional observations to those already detailed were instigated at the discretion of the study director. In certain instances this included treatment as advised by a Covance veterinary surgeon. Animals were kept according to the German Animal Protection Law ("Tierschutzgesetz"), dated 25 May 1998.

\section{Study procedures}

SH-SY5Y cells were cultured in RPMI 1640 medium (Gibco, Karlsruhe, Germany) containing $10 \%$ fetal calf serum (FCS; PAA, Coelbe, Germany), 2 mML glutamine and $1 \%$ penicillin-streptomycin, in an atmosphere containing $5 \% \mathrm{CO} 2$ and $95 \%$ air at $37{ }^{\circ} \mathrm{C}$. Prior to and during treatments, $5 \%$ dextran-coated charcoal (DCC) steroid-depleted fetal calf serum (FCS) was used. Hippocampus tissues from non-human primates were removed during necropsy, washed with $0.06 \mathrm{M}$ Tris- $\mathrm{HCl}$ buffer $\mathrm{pH}$ 7.0, immediately frozen in liquid nitrogen, and kept at $-70{ }^{\circ} \mathrm{C}$ until analysis. Black cohosh (iCR) and steroids (E2, T, Org4094) were added from stock solutions and diluted in culture medium resulting in a final concentration of less than $0.5 \%$ isopropanol (iCR) and $0.1 \%$ ethanol (hormones), respectively. The same concentration of isopropanol and ethanol was present in the control samples, respectively. The medium containing fresh iCR and steroids was replaced every 2 days. ICR was used at a concentration of $10 \mu \mathrm{g} / \mathrm{ml}$ and $1 \mu \mathrm{g} / \mathrm{ml}$, whereas E2, T and Org4094 were used at a concentration of $10^{-8}$ and $10^{-6} \mathrm{M}$, respectively. Neuroblastoma cells were incubated in RPMI 1640 medium containing $5 \%$ steroiddepleted FCS for 3 days, and subsequently incubated in the presence or absence of iCR and steroids for either $24 \mathrm{~h}$, or enzyme activity was determined directly in cell 
extracts ("direct"). In hippocampus tissue, enzyme activity was measured directly ("direct") after incubation with the respective substance.

\section{E1S-sulfatase (STS) activity assay}

STS activity was measured as described previously [15]. In brief, SH-SY5Y cells were homogenized on ice, in $2 \mathrm{ml} 0.06 \mathrm{M}$ Tris-HCl-buffer $\mathrm{pH} 7.0$ (assay buffer throughout the entire procedure) for approximately $1 \mathrm{~min}$ at maximum speed using a Polytron ${ }^{\circ}$ homogenizer (Kinematica, AG). Hippocampus tissue (2 mg) was finely minced with scissors and homogenized accordingly. All incubations were carried out in duplicate. The incubation mixtures consisted of $200 \mu \mathrm{l}$ homogenate, $19.39 \mathrm{pmol}[3 \mathrm{H}]$-E1S in $100 \mu \mathrm{l}$ of buffer, and $100 \mu \mathrm{g}$ of NADH and NADPH in $100 \mu \mathrm{l}$ of buffer (total incubation volume $400 \mu \mathrm{l}$ ). Simultaneous background incubations using buffer instead of cell and tissue homogenate, respectively, were performed in order to correct for non-enzymatic transformation of the substrate. After $15 \mathrm{~min}$ of incubation in air at $37{ }^{\circ} \mathrm{C}$ in a water bath, $200 \mu \mathrm{g}$ of non-radioactive E1 and E2 were added in $100 \mu \mathrm{l}$ of ethanol together with $0.5 \mathrm{ml}$ of $0.5 \mathrm{M}$ sodium phosphate buffer, $\mathrm{pH}$ 7.0. The unconjugated steroids were extracted with $2.0 \mathrm{ml}$ toluene. After inverting the tubes 100 times they were centrifuged at $1500 \times \mathrm{g}$ for $10 \mathrm{~min}$. The lower aqueous phase was frozen in liquid nitrogen Folch-Solution (2:1 chloroform:methanol). Thin layer chromatography (TLC) on Alugram Sil G/UV 254 (Roth; Macherey-Nagel Düren, Germany) was performed using $13 \%$ ethanol in toluene as solvent. After visualization in $254 \mathrm{~nm}$ UV light, the zones in the plate corresponding to the estrogens as well as the non-fluorescent zones were cut apart and separately eluted with $3 \mathrm{ml}$ ethanol and $6 \mathrm{ml}$ scintillation fluid. Aliquots were taken from each fraction from the TLC plate for counting of the $[3 \mathrm{H}]$ activity. A Wallac 1409 (ß-Counter) scintillation spectrometer was used for the radioactivity measurements and Riafluor ${ }^{\circ}$ (New EnglandNuclear Corporation, Boston, MA, USA) was used as scintillation fluid. The enzyme activity was expressed as the amount of unconjugated estrogen $(E 1+E 2)$ formed per minute and per milligram of protein (E1 + E2 fmol/mg of protein/ min). The total protein was determined by the method of Bradford [16].

\section{Statistical methods}

Results were expressed as the mean \pm standard error of the mean (S.E.M.). Statistical comparisons were made using unpaired $T$-Test for comparing two sets of data and ANOVA to compare many groups at once. A $p$ value $<0.05$ was considered to be significant different.
All cell culture treatment experiments were repeated four times. Negative STS activity values were set to zero and repeated measures were aggregated by calculating the mean.

\section{Results}

\section{Basal estrogen formation as indicative for brain STS} activity

Basal E1, E2 and total estrogen formation (E1 + E2) were assessed in untreated SH-SY5Y cells and hippocampus tissue of non-human primates. Irrespective of incubation duration ("direct", "24 h"), E2 was the most abundant labeled estrogen found after incubation with labeled E1S. On average, the concentration of locally formed E2 was about 22 times (SH-SY5Y cells) and 12 times (hippocampus) higher than that of E1, respectively. In SH-SY5Y cells, mean basal total estrogen formation $(\mathrm{E} 1+\mathrm{E} 2)$ did not differ between "direct" and "24 h" incubation ("direct": $1350.06 \pm 109 \mathrm{fmol} / \mathrm{mg}$ of protein $/ \mathrm{min}(n=15)$ vs. "24 h": $1515.87 \pm 72 \mathrm{fmol} / \mathrm{mg}$ of protein $/ \mathrm{min}(n=10)$; $p>0.06)$. However, the corresponding value from hippocampus tissue $(n=14)$ after "direct"incubation was $37.83 \pm 3.9 \mathrm{E} 1+\mathrm{E} 2 \mathrm{fmol} / \mathrm{mg}$ of protein/min, thus being significantly lower than basal total estrogen formation in SH-SY5Y cells $(p<0.01)$. For comparison between groups, the respective control levels of basal total estrogen formation $(\mathrm{E} 1+\mathrm{E} 2)$ were set to $100 \%$ and the percentage changes after "direct"or " 24 h"treatment with iCR, E2, T, and Org4094 were calculated.

\section{Impact of black cohosh on brain STS activity}

„Direct"incubation with iCR at $10 \mu \mathrm{g} / \mathrm{ml}$ and $1 \mu \mathrm{g} / \mathrm{ml}$ significantly decreased STS activity (E1 + E2 formation/ $\mathrm{mg}$ of protein $/ \mathrm{min})$ in SH-SY5Y cells $(n=5)$ and hippocampus tissue $(n=14)$ in a dose-dependent manner $(p<$ 0.01 ) (Fig. 1). The inhibitory effect was significantly more pronounced in proliferative SH-SY5Y cells compared to hippocampus tissue $(p<0.01)$. However, in SHSY5Y cells $(n=5)$ after " 24 h"incubation with iCR total estrogen formation (E1 + E2) significantly increased almost reaching baseline levels again for iCR at $1 \mu \mathrm{g} / \mathrm{ml}$. In cells treated with iCR at $10 \mu \mathrm{g} / \mathrm{ml}$ for " 24 h"total estrogen formation $(\mathrm{E} 1+\mathrm{E} 2)$ significantly exceeded baseline levels by $85 \%(p<0.001)$. The dose-dependent difference in total estrogen formation after "24 h" was significant $(p<0.01)$.

\section{Impact of selected steroids on brain STS activity}

In a next step, SH-SY5Y cells $(n=5)$ and hippocampus tissue $(n=3)$ were treated with E2 at $10^{-6} \mathrm{M}$ and $10^{-8}$ M, respectively (Fig. 2). „Direct"incubation with E2 did not have a significant impact on total estrogen formation $(\mathrm{E} 1+\mathrm{E} 2)$ in SH-SY5Y cells but slightly albeit significantly reduced STS activity in hippocampus tissue by $6 \%$ at 10 


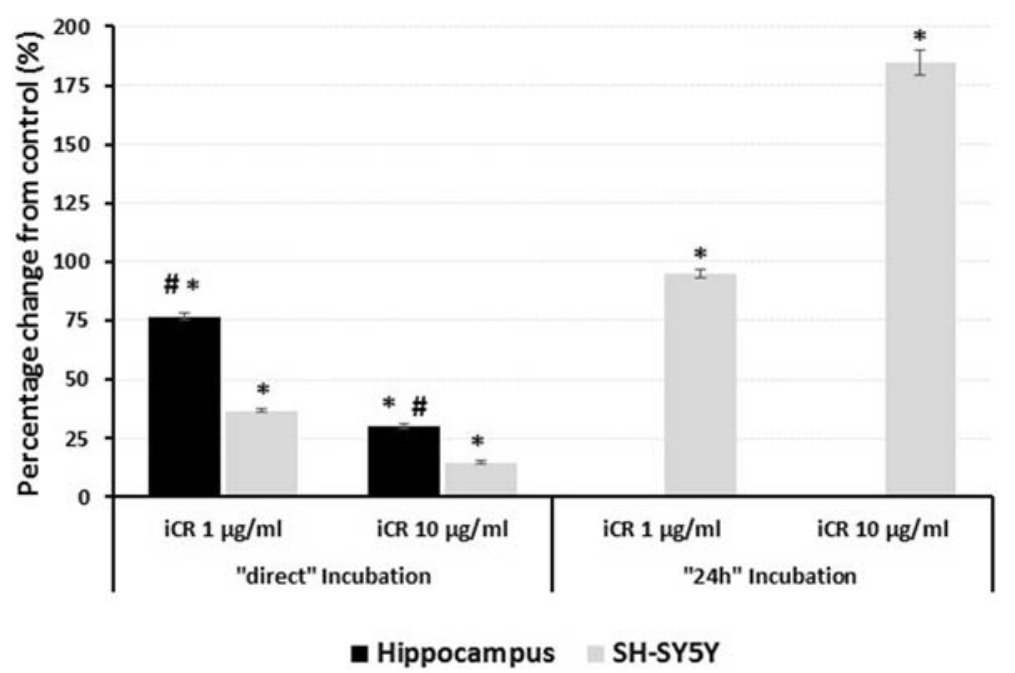

Fig. 1 Impact of black cohosh (iCR) on STS activity in SH-SY5Y cells $(n=5)$ and hippocampus tissue from non-human primates $(n=14)$. Data are presented as percentage change from control. Abbreviations: ${ }^{*} p<0.01$ from controls; $\# p<0.01$ hippocampus vs. SH-SY5Y

${ }^{-8} \mathrm{M}(p<0.01)$. The inhibitory effect became more pronounced after " 24 h"incubation with E2 at $10^{-6} \mathrm{M}$ in SH-SY5Y cells revealing a STS activity reduction by $23 \%$ $(p<0.001)$. However, E2 at $10^{-8} \mathrm{M}$ had an opposite effect as it significantly increased STS activity by $18 \%(p<0.001)$.

In an exploratory attempt, SH-SY5Y cells $(n=5)$ and hippocampus tissue $(n=3)$ were treated with either T or Org4049 at $10^{-6} \mathrm{M}$ and $10^{-8} \mathrm{M}$, respectively (Fig. 3). „Direct"incubation with $\mathrm{T}$ at $10^{-6} \mathrm{M}$ and $10^{-8} \mathrm{M}$ had opposed effects on STS activity in SH-SY5Y cells. T at the higher concentration significantly decreased STS activity by about $88 \%(p<0.001)$, while the lower concentration led to a non-significant $16 \%$ increase compared to baseline activity $(p=0.09)$. After " $24 \mathrm{~h}$ "incubation with T, either concentration significantly decreased total estrogen formation $(\mathrm{E} 1+\mathrm{E} 2)$ by about $30 \%(p<0.001)$. In hippocampus tissue, Org4094 significantly reduced STS activity in a dose-dependent manner $(p<0.05)$.

When comparing the impact of different compounds on hippocampus tissue (Fig. 4), total estrogen formation $(E 1+E 2)$ was lowest after treatment with Org4040 at 10 ${ }^{-6} \mathrm{M}$, highest after treatment with E2 $\left(10^{-6}\right.$ and $\left.10^{-8} \mathrm{M}\right)$, and in-between with $\mathrm{iCR}$ treatment, respectively (iCR at $1 \mu \mathrm{g} / \mathrm{ml}$ vs. E2 at $\left.10^{-6} / 10^{-8} \mathrm{M} ; p<0.001\right)$.

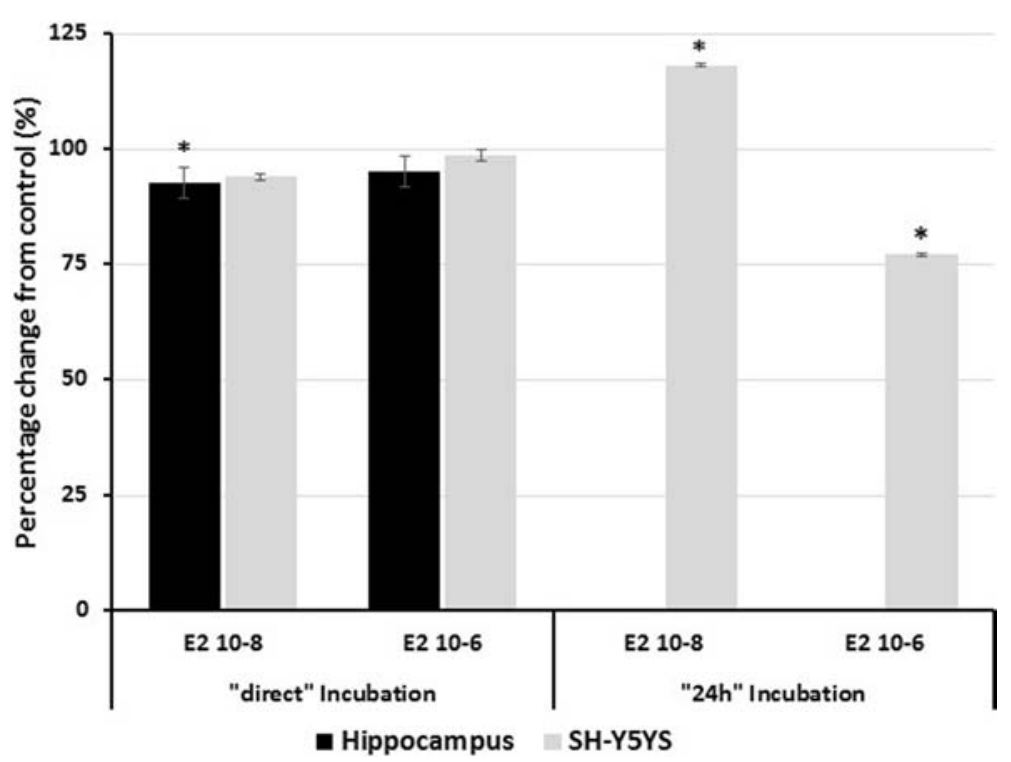

Fig. 2 Impact of estradiol (E2) on STS activity in SH-SY5Y cells $(n=5)$ and hippocampus tissue from non-human primates $(n=3)$. Data are presented as percentage change from control. Abbreviations: ${ }^{*}=p<0.01$ from controls 


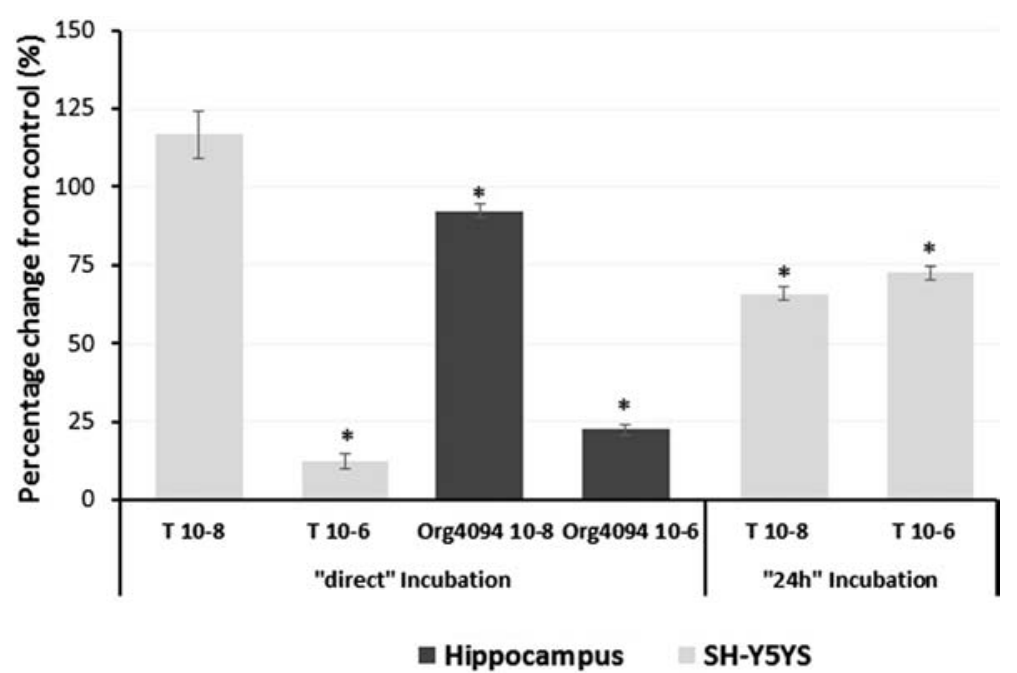

Fig. 3 Impact of testosterone (T) and Org4049 on STS activity in SH-SY5Y cells $(n=5)$ or hippocampus tissue from non-human primates $(n=3)$. Data are presented as percentage change from control. Abbreviations: ${ }^{*}=p<0.01$ from controls

When comparing the impact of $\mathrm{iCR}, \mathrm{E} 2$ and $\mathrm{T}$ on total estrogen formation (E1 + E2) in SH-SY5Y cells, significant treatment differences almost only occurred for "direct" incubation. In detail, iCR at $1 \mu \mathrm{g} /$ $\mathrm{ml}$ had a significantly stronger inhibitory effect on STS activity compared to E2 at $10^{-6} \mathrm{M}$ and $\mathrm{T}$ at 10 ${ }^{-6}$ and $10^{-8} \mathrm{M}$, respectively $(p<0.001)$. In contrast, total estrogen formation was significantly lower after "24 h" incubation with $\mathrm{T}$ at $10^{-6}$ and $10^{-8} \mathrm{M}$ compared to iCR at $1 \mu \mathrm{g} / \mathrm{ml}(p<0.001)$. Accordingly, there were no significant differences in total estrogen formation when comparing the effect of E2 and T; neither during "direct" nor during " $24 \mathrm{~h}$ " incubation.

\section{Discussion}

To our knowledge, we are the first to report on the impact of black cohosh (iCR), 17ß-estradiol (E2), testosterone (T) and Tibolone's $3 \alpha-\mathrm{OH}$ metabolite (Org4049) on brain STS activity in proliferative human neuroblastoma cells in vitro and benign hippocampus tissue from nonhuman primates ex vivo in vitro. We found that 1 ) both, SH-SY5Y cells and hippocampus tissue, possessed the enzymes necessary (at least STS, 17ßHSD1) to produce E2 from E1S, 2) total estrogen formation $(E 1+E 2)$ was significantly higher in proliferative SH-SY5Y cells compared to benign hippocampus tissue, 3 ) iCR exerted a bidirectional action that was an immediate strong

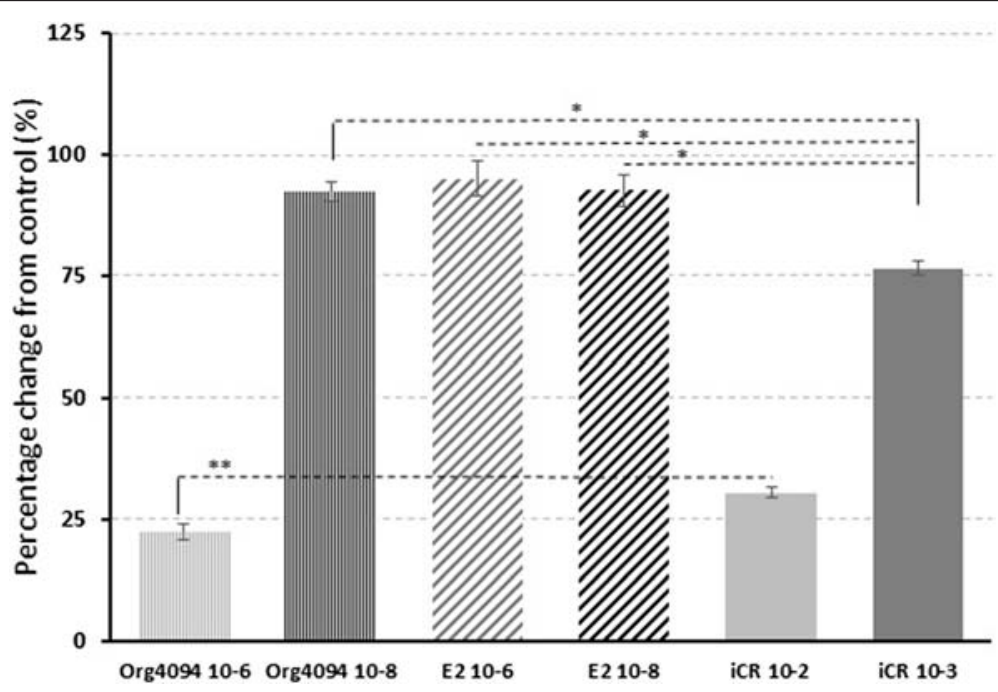

Fig. 4 Comparison of effects of iCR, E2 and Org 4094 on STS activity in hippocampus tissue. Data are presented as percentage change from control. Abbreviations: ${ }^{*}=p<0.001$ from controls; ${ }^{* *}=p<0.05$ from controls 
inhibitory effect followed by a stimulation of STS activity (85\% increase), 4) E2 had a bidirectional dosedependent long-term effect on STS activity $(-23 \%$ reduction and $18 \%$ increase) with the latter being less pronounced compared to $\mathrm{iCR}, 5)$ similar to $\mathrm{iCR}, \mathrm{T}$ and Org4094 had an immediate strong inhibitory effect on STS activity that was, however, further maintained with $24 \mathrm{~h} \mathrm{~T}$ treatment (30\% decrease), and 6) differences in treatment effects mainly occurred after "direct" incubation and were less pronounced in the long-term.

Proliferative human neuroblastoma SH-SY5Y cells were originally derived from a metastatic bone tumor biopsy and behave therefore like malignant tumor cells. On the contrary, brain tissue from healthy animals contains differentiated non-proliferative neurons.

Our finding that STS activity was higher in malignant than healthy cells and tissue, respectively, is in accordance with previous studies in breast cells [15] and brain tumors [17]. Other factors might also contribute to the differences observed such as species (human vs. monkey), origin of investigated material (SH-SY5Y cells obtained from bone marrow biopsy vs. hippocampus tissue obtained from brain necropsy), culture conditions (cells vs. tissue), and the hormonal environment. However, the latter possibly does not have a major impact since the hormonal environment was expected to be lowestrogenic in both, SH-SY5Y cells (obtained from a prepubertal girl) and hippocampus tissue (obtained from lactating monkeys).

"Direct" incubation, which eliminates cellular regulation of metabolism, led to a reduction of estrogen biosynthesis regardless of treatment. By "direct" incubation, we believe to obtain more valid information about regulation of the selected compounds at the level of the enzyme's catalytic activity. Our findings in brain are in agreement with previous studies in malignant breast cells and normal mammary gland, demonstrating an inhibitory effect on STS activity after "direct" incubation by iCR [18], E2 [15], T [19] and Org4094 [15], respectively.

In contrast, longer incubation in intact cells and tissues also includes complex effects on STS expression, and on downstream processing of metabolites, making it difficult to differentiate between the respective effects. Accordingly, "24 h" incubation with the respective compounds yielded different results being either inhibitory on STS activity (E2, T, Org4094) or stimulating (iCR, E2), respectively. In brain tissue a positive increase in STS activity would be expected to be more beneficial promoting the reported neuro-protective and -reparative effects [1].

Black cohosh, specifically, iCR has been shown to have an impact on brain via modulating neurotransmitter receptors in vitro [20-23] and in vivo in rodents [14, 24] as well as in humans $[25,26]$. There is pharmacodynamic evidence for bioactivity of iCR-ingredients in brain in vivo, i.e. passing of the blood brain barrier. During menopause, the decline of circulating estrogens coincidences with the decline of brain bioenergetics and a shift towards a metabolically compromised phenotype [27]. Oral administration of iCR or E2 for 1 week to ovariectomized rats was able to restore neuronal excitability leading to functional recovery of hypothalamic activity $[14,24]$. Furthermore, iCR has been shown to upregulate genes related to cell survival under metabolic stress such as hypoxia [28-30]. In hypoestrogenic women, the cerebral blood flow has been shown to be reduced with regional patterns resembling those of patients with mild to moderate Alzheimer's disease [31]. This mechanism has been hypothesized be the initiating event in the metabolic process that results in dementia of the Alzheimer's type, and thus may serve as the link between hypoestrogenism and neurodegenerative diseases.

E2 has been shown to display beneficial effects on the entire bioenergetic system of the brain, e.g., from glucose transport into cells to glycolysis, and ATP production $[27,32]$. Recent evidence is pointing to the mitochondrial respiratory chain as a novel and important target for the actions of E2 and its receptors (ER), especially in cells and tissues with high demands for mitochondrial energy metabolism [33]. This E2-mediated pathway involves the cooperation of both, nuclear and mitochondrial ER $\alpha$ and ER $\beta$, and their co-activators for the regulation of both, nuclear DNA- and mitochondrial DNA-encoded genes for the mitochondrial respiratory chain proteins [33]. Stimulation of the E2/ER-mediated mitochondrial respiratory chain pathway could be highly beneficial in brain, whereas impairment could be causally related to the pathogenesis of neurodegenerative/ cognitive disorders [33, 34].

Our study has some limitations. We were only able to examine hippocampus tissue and not other regions involved in cognition. Similarly, due to limited tissue availability, we could only assess STS activity, but not other enzymes. Given the opposing effect of conjugated and unconjugated neurosteroids on neurotransmitter signaling the comparison of the expression of the e.g. $\mathrm{GABA}_{\mathrm{A}}$ signaling cascade components before and after treatment would have been of interest. We also acknowledge that within brain tissue there are multiple cell types such as astrocytes and microglia, oligodendrocytes, neurons as well as blood vessels. Thus we cannot differentiate between their impacts on our results in hippocampus tissue. However, this is why we included neuroblastoma cells as model for a "single neuron system".

Our results contribute to our previous work showing that local STS activity can be modulated by exogenous 
steroids and black cohosh $[15,18,19,34]$ - also in brain (this study). This might be one explanation as to how those compounds frequently used in menopausal women may affect cognition.

\section{Conclusion}

We showed that in vitro local estrogen formation within brain cells and tissue was modulated by black cohosh (iCR), 17ß-estradiol, testosterone, and Tibolone's $3 \alpha-\mathrm{OH}$ metabolite, respectively. While short-term effects on STS activity were different for the compounds studied, the long-term effects in vitro were less pronounced being either inhibitory (E2, T, Org4094) or stimulating (iCR, E2), respectively. The clinical implication of this finding has to be elucidated.

\section{Competing interests}

Petra Stute received compensation for consulting Schaper \& Bruemmer GmbH \& Co. KG, 38259 Salzgitter (Germany) and NV Organon (Oss, the Netherlands). Hans-Heinrich Henneicke-von Zepelin and Susana Garcia de Arriba are employees at Schaper \& Bruemmer GmbH \& Co. KG, 38259 Salzgitter (Germany). Gunnar Habermann and Ludwig Kiesel do not have competing interests.

\section{Authors' contributions}

PS carried designed the study, supervised the experimental part of the study and drafted the manuscript. GH provided the tissue samples and helped to draft the manuscript. LK and HHHvZ helped to draft the manuscript. SGdA performed the statistical analysis and helped to draft the manuscript. All authors read and approved the final manuscript.

\section{Acknowledgements}

The authors would like to thank K. Brunswicker and D. Godulla, University clinic of Muenster, for expert technical assistance. We are also grateful for the support of Klaus-Ulrich Nolte, Head of Regulatory Affairs at Schaper \& Bruemmer GmbH \& Co.KG.

\section{Funding}

Purchase of chemicals, reagents, and steroids was financially supported by Schaper \& Bruemmer GmbH \& Co.KG. Salzgitter (Germany) and NV Organon (Oss, the Netherlands).

\section{Author details}

'Department of Obstetrics and Gynecology, Inselspital, University Hospital and University of Bern, Effingerstrasse 102, 3010 Bern, Switzerland. ${ }^{2}$ Covance Preclinical Services GmbH, Kesselfeld 29, 48163 Münster, Germany. ${ }^{3}$ Department of Obstetrics and Gynecology, University Clinic Muenster, Albert-Schweitzer-Strasse 33, 48149 Muenster, Germany. ${ }^{4}$ Schaper \& Bruemmer GmbH \& Co. KG, 38259 Salzgitter, Germany. ${ }^{5}$ Department of Obstetrics and Gynecology, Section Gynecologic Endocrinology and Reproductive Medicine, Inselspital Bern, Effingerstrasse 102, 3010 Bern, Switzerland.

Received: 3 September 2015 Accepted: 8 January 2016

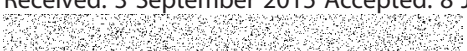

\section{References}

1. Azcoitia I, Arevalo MA, De Nicola AF, Garcia-Segura LM. Neuroprotective actions of estradiol revisited. Trends Endocrinol Metab. 2011;22(12):467-73. doi:10.1016/.jtem.2011.08.002.

2. Henderson WW. Alzheimer's disease: review of hormone therapy trials and implications for treatment and prevention after menopause. I Steroid Biochem Mol Biol. 2014;142:99-106. doi:10.1016/j.jsbmb.2013.05.010.

3. Jo DH, Abdallah MA, Young J, Baulieu EE, Robel P. Pregnenolone, dehydroepiandrosterone, and their sulfate and fatty acid esters in the rat brain. Steroids. 1989;54(3):287-97.

4. Baulieu EE, Robel P. Dehydroepiandrosterone and dehydroepiandrosterone sulfate as neuroactive neurosteroids. J Endocrinol. 1996;150(Suppl):S221-39.
5. Kriz L, Bicikova M, Hampl R. Roles of steroid sulfatase in brain and other tissues. Physiol Res. 2008;57(5):657-68.

6. Flood JF, Smith GE, Roberts E. Dehydroepiandrosterone and its sulfate enhance memory retention in mice. Brain Res. 1988;447(2):269-78.

7. Yoo A, Harris J, Dubrovsky B. Dose-response study of dehydroepiandrosterone sulfate on dentate gyrus long-term potentiation. Exp Neurol. 1996;137(1):151-6. doi:10.1006/exnr.1996.0015.

8. Rhodes ME, Li PK, Burke AM, Johnson DA. Enhanced plasma DHEAS, brain acetylcholine and memory mediated by steroid sulfatase inhibition. Brain Res. 1997;773(1-2):28-32.

9. Li PK, Rhodes ME, Burke AM, Johnson DA. Memory enhancement mediated by the steroid sulfatase inhibitor (p-O-sulfamoyl)-N-tetradecanoyl tyramine. Life Sci. 1997;60(3):L45-51.

10. Demirgoren S, Majewska MD, Spivak CE, London ED. Receptor binding and electrophysiological effects of dehydroepiandrosterone sulfate, an antagonist of the GABAA receptor. Neuroscience. 1991;45(1):127-35.

11. Hosie AM, Wilkins ME, da Silva HM, Smart TG. Endogenous neurosteroids regulate GABAA receptors through two discrete transmembrane sites. Nature. 2006:444(7118):486-9. doi:10.1038/nature05324.

12. de Villiers TJ, Pines A, Panay N, Gambacciani M, Archer DF, Baber RJ, et al. Updated 2013 International Menopause Society recommendations on menopausal hormone therapy and preventive strategies for midlife health. Climacteric. 2013;16(3):316-37. doi:10.3109/13697137.2013.795683.

13. Wierman ME, Arlt W, Basson R, Davis SR, Miller KK, Murad MH, et al. Androgen therapy in women: a reappraisal: an Endocrine Society clinical practice guideline. J Clin Endocrinol Metab. 2014;99(10):3489-510. doi:10. 1210/jc.2014-2260.

14. Garcia de Arriba S, Dimpfel W, Henneicke-von Zepelin HH, Zhang H, Bai W, Nolte KU. Neuroprotective effects of Cimicifuga racemosa may be able to prevent age-related neurodegeneration. Z Phytotherapie. 2013;34(S 01):1.

15. Stute $P$, Gotte M, Kiesel L. Differential effect of hormone therapy on E1Ssulfatase activity in non-malignant and cancerous breast cells in vitro. Breast Cancer Res Treat. 2008;108(3):363-74. doi:10.1007/s10549-007-9615-7.

16. Bradford MM. A rapid and sensitive method for the quantitation of microgram quantities of protein utilizing the principle of protein-dye binding. Anal Biochem. 1976;72:248-54.

17. Kriz L, Bicikova M, Mohapl M, Hill M, Cerny I, Hampl R. Steroid sulfatase and sulfuryl transferase activities in human brain tumors. J Steroid Biochem Mol Biol. 2008;109(1-2):31-9. doi:10.1016/j.jsbmb.2007.12.004.

18. Stute P, Nisslein T, Gotte M, Kamischke A, Kiesel L, Klockenbusch W. Effects of black cohosh on estrogen biosynthesis in normal breast tissue in vitro. Maturitas. 2007;57(4):382-91. doi:10.1016/j.maturitas.2007.04.007.

19. Gotte M, Kalkhake K, Ploeger S, Kiesel L, Stute P. Effect of testosterone on E1Ssulfatase activity in non-malignant and cancerous breast cells in vitro. J Steroid Biochem Mol Biol. 2009;117(4-5):168-75. doi:10.1016/j.jsbmb.2009.09.007.

20. Burdette JE, Liu J, Chen SN, Fabricant DS, Piersen CE, Barker EL, et al. Black cohosh acts as a mixed competitive ligand and partial agonist of the serotonin receptor. J Agric Food Chem. 2003;51(19):5661-70. doi:10.1021/jf034264r.

21. Rhyu MR, Lu J, Webster DE, Fabricant DS, Farnsworth NR, Wang ZJ. Black cohosh (Actaea racemosa, Cimicifuga racemosa) behaves as a mixed competitive ligand and partial agonist at the human mu opiate receptor. J Agric Food Chem. 2006;54(26):9852-7. doi:10.1021/jf062808u.

22. Woo KC, Park YS, Jun DJ, Lim JO, Baek WY, Suh BS, et al. Phytoestrogen cimicifugoside-mediated inhibition of catecholamine secretion by blocking nicotinic acetylcholine receptor in bovine adrenal chromaffin cells. J Pharmacol Exp Ther. 2004;309(2):641-9. doi:10.1124/jpet.103.062331.

23. Jarry H, Metten $M$, Spengler $B$, Christoffel V, Wuttke W. In vitro effects of the Cimicifuga racemosa extract BNO 1055. Maturitas. 2003;44 Suppl 1:S31-8.

24. Nadaoka I, Yasue M, Sami M, Kitagawa Y. Oral administration of Cimicifuga racemosa extract affects immobilization stress-induced changes in murine cerebral monoamine metabolism. Biomed Res. 2012;33(2):133-7.

25. Reame NE, Lukacs JL, Padmanabhan V, Eyvazzadeh AD, Smith YR, Zubieta JK. Black cohosh has central opioid activity in postmenopausal women: evidence from naloxone blockade and positron emission tomography neuroimaging. Menopause. 2008;15(5):832-40. doi:10.1097/gme. Ob013e318169332a.

26. Nadaoka I, Yasue M, Kitagawa Y, Koga Y. Oral administration of Cimicifuga racemosa extract attenuates psychological and physiological stress responses. Biomed Res. 2012;33(3):145-52.

27. Henderson WW. Cognitive changes after menopause: influence of estrogen. Clin Obstet Gynecol. 2008;51(3):618-26. doi:10.1097/GRF.0b013e318180ba10. 
28. Gaube F, Wolfl S, Pusch L, Kroll TC, Hamburger M. Gene expression profiling reveals effects of Cimicifuga racemosa (L.) NUTT. (black cohosh) on the estrogen receptor positive human breast cancer cell line MCF-7. BMC Pharmacol. 2007:7:11. doi:10.1186/1471-2210-7-11.

29. Einbond LS, Su T, Wu HA, Friedman R, Wang X, Ramirez A, et al. The growth inhibitory effect of actein on human breast cancer cells is associated with activation of stress response pathways. Int J Cancer. 2007;121(9):2073-83. doi:10.1002/ijc.22897.

30. Einbond LS, Su T, Wu HA, Friedman R, Wang X, Jiang B, et al. Gene expression analysis of the mechanisms whereby black cohosh inhibits human breast cancer cell growth. Anticancer Res. 2007;27(2):697-712.

31. Greene RA. Estrogen and cerebral blood flow: a mechanism to explain the impact of estrogen on the incidence and treatment of Alzheimer's disease. Int J Fertil Womens Med. 2000;45(4):253-7.

32. Rettberg JR, Yao J, Brinton RD. Estrogen: a master regulator of bioenergetic systems in the brain and body. Front Neuroendocrinol. 2014;35(1):8-30. doi: 10.1016/j.yfrne.2013.08.001

33. Chen JQ, Cammarata PR, Baines CP, Yager JD. Regulation of mitochondrial respiratory chain biogenesis by estrogens/estrogen receptors and physiological, pathological and pharmacological implications. Biochim Biophys Acta. 2009;1793(10):1540-70. doi:10.1016/j.bbamcr.2009.06.001.

34. Stute $\mathrm{P}$, Kalkhake $\mathrm{K}$, Kiesel L, Gotte M. The impact of testosterone, tibolone and black cohosh on purified mammary and placental 17betahydroxysteroid dehydrogenase type 1. J Enzyme Inhib Med Chem. 2015; 30(3):448-57. doi:10.3109/14756366.2014.943205.

\section{Submit your manuscript to a SpringerOpen ${ }^{\odot}$ journal and benefit from:}

- Convenient online submission

- Rigorous peer review

- Immediate publication on acceptance

- Open access: articles freely available online

- High visibility within the field

- Retaining the copyright to your article

Submit your next manuscript at $\boldsymbol{s p r i n g e r o p e n . c o m ~}$ 